\title{
EFEKTIFKAH PELAKSANAAN PENJAMINAN MUTU MELALUI AKREDITASI LEMBAGA PELATIHAN PEMERINTAH DI INDONESIA?
}

\section{THE IMPLEMENTATION OF QUALITY ASSURANCE THROUGH ACCREDITATION OF INDONESIA'S GOVERNMENT TRAINING CENTER: IS IT EFFECTIVE?}

\author{
Erna Irawati a dan Yogi Suwarno ${ }^{b}$ \\ a Lembaga Administrasi Negara \\ Jalan Veteran No. 10 Jakarta Pusat, \\ b Politeknik STIA LAN Jakarta \\ Jalan Administrasi II Pejompongan Jakarta Pusat \\ Email: ernairawati99@yahoo.com,yogi@stialan.ac.id
}

Naskah diterima: 9 Juni 2020; revisi terakhir: 16 November 2020; disetujui: 7 Desember 2020

How to Cite: Irawati, Erna dan Suwarno, Yogi. (2020). Efektifkah Pelaksanaan Penjaminan Mutu Melalui Akreditasi Lembaga Pelatihan Pemerintah di Indonesia. Jurnal Borneo Administrator, 16 (3), 291-312. https://doi.org/10.24258/jba.v16i3.713

\begin{abstract}
The implementation of ASN competency development is closely related to the quality of education and training provided by the Educational Institution (Lemdik). The National Institute of Public Administration (NIPA) as the agency assigned the task of fostering the implementation of education and training for ASN employees has conducted quality assurance to ensure the implementation quality of the education and training. Even though quality assurance has been carried out routinely, training problems still arise. This study aims to analyze the implementation of accreditation as a quality assurance process carried out by Educational Institutions. This research was conducted using qualitative descriptive method with data collection techniques through document review, FGDs, and in-depth interviews. The results of the study showed that the implementation of accreditation has not been able to portray aspects of leadership and organizational commitment as part of quality assurance. The results of the study found that the fulfillment of data and information in the implementation of accreditation had not been carried out routinely. From these findings, the results of the study recommended that the quality assurance process must be viewed from the management cycle. Besides, there also needs an improvement in data and information management systems.
\end{abstract}

Keywords: State Civil Apparatus (ASN), Quality Management, Accreditation, Competency Development 


\begin{abstract}
Abstrak
Pelaksanaan pengembangan kompetensi ASN berkaitan erat dengan kualitas penyelenggaraan diklat yang diberikan oleh Lembaga Pendidikan (Lemdik). Lembaga Administrasi Negara (LAN) sebagai instansi yang diberikan tugas dalam membina pelaksanaan pendidikan dan pelatihan pegawai ASN telah melakukan penjaminan mutu untuk menjamin kualitas penyelenggaraan diklat. Meskipun penjaminan mutu telah dilaksanakan secara rutin, tetapi permasalahan diklat masih sering muncul. Penelitian ini bertujuan menganalisis pelaksanaan akreditasi sebagai proses penjaminan mutu yang dilakukan oleh lemdik. Penelitian ini dilakukan dengan menggunakan metode deskriptif kualitatif dengan teknik pengumpulan data melalui telaah dokumen dengan memanfaatkan berbagai dokumen terkait proses akreditasi tahun 2019, FGD, dan wawancara mendalam. Hasil studi menunjukkan bahwa pelaksanaan akreditasi belum mampu memotret aspek kepemimpinan dan juga komitmen organisasi sebagai bagian dari penyelenggaraan penjaminan mutu. Hasil kajian menemukan pemenuhan data dan informasi dalam pelaksanaan akreditasi belum dilakukan secara rutin sehingga menyebabkan data dan informasi yang diberikan cenderung disiapkan hanya untuk keperluan akreditasi. Dari dua temuan ini, hasil kajian merekomendasikan bahwa proses penjaminan kualitas harus dilihat dari siklus manajemen, serta perlu penambahan data dan informasi yang mencerminkan aspek kepemimpinan, integritas dan komitmen pegawai. Selain itu, perlu ada perbaikan sistem pengelolaan data dan informasi untuk menjamin bahwa data yang diunggah benar-benar mencerminkan aktivitas dan penjaminan kualitas di setiap tahapan.
\end{abstract}

Kata kunci: ASN, Manajemen Mutu, Akreditasi, Pengembangan Kompetensi

\title{
A. PENDAHULUAN
}

Aparatur Sipil Negara (ASN) memiliki peran yang sangat strategis sebagai agen pembangunan dan penggerak roda birokrasi. Sebagai agen pembangunan, ASN merupakan prasyarat birokrasi 4.0 dalam melakukan percepatan pelayanan dan memberikan pelayanan yang efisien. Sebagai penggerak roda birokrasi, ASN diharapkan lebih profesional, inovatif dan strategis dalam menangani permasalahan dalam masyarakat dan juga pengelolaan urusan kepublikan lainnya (termasuk pengelolaan kebutuhan masyarakat yang dikelola oleh sektor swasta). Inti administrasi negara terletak pada kedua hal tersebut, public affairs dan public business (Thoha, 2008:7). Kehadiran dan peran negara ini tidak dapat dilepaskan dari peran ASN yang merupakan kunci utama reformasi birokrasi, agar negara dapat menampilkan kemampuan pelayanan yang optimal dan dapat meningkatkan kesejahteraan masyarakat (Rahman \& Bakri, 2019:4).

Manajemen kinerja di Indonesia khususnya di sektor publik masih berada pada tahap transisi yang memerlukan langkah percepatan dalam mencapai manajemen kinerja kelas dunia (Rhodes et al., 2012:235). Langkah ini dimulai dengan memberikan perhatian khusus kepada ASN sebagai sumber daya manusia (SDM) berkualitas, berdaya saing, dan menjadi penggerak birokrasi. Salah satu program aksi pemerintah adalah dengan reformasi pendidikan dan pelatihan ASN agar lebih sinergis menjadi learning governance ( $\underline{P K}$ bangkom ASN, 2020). Perubahan paradigma Pendidikan Pelatihan ke Pengembangan Kompetensi (dari Training and Development menjadi Learning and Development) masih menempatkan Pendidikan dan pelatihan (Diklat) menjadi salah satu bentuk pengembangan kompetensi bagi ASN sebagaimana diatur dalam Undang-Undang (UU) Nomor 5 Tahun 2014 tentang Aparatur Sipil Negara. Diklat atau Pelatihan diselenggarakan oleh lembaga pelatihan pemerintah baik tingkat pusat (kementerian dan nonkementerian) maupun daerah 
(pemerintah provinsi dan pemerintah kabupaten/kota) yang tersebar di seluruh Indonesia bertujuan untuk meningkatkan kompetensi manajerial, teknis fungsional dan sosiokultural ASN.

Kualitas penyelenggaraan pelatihan yang berdampak pada hasil pelatihan (peningkatan kompetensi ASN) berkaitan erat dengan kualitas lembaga penyelenggaranya. Oleh karena itu, pemerintah perlu memastikan kualitas penyelenggaraan pelatihan yang dilakukan oleh lembaga pendidikan (lemdik). Lembaga Administrasi Negara (LAN) sebagai instansi yang diberikan tugas dalam membina dan menyelenggarakan pendidikan dan pelatihan ASN (UU No. 5 Tahun 2014) telah melakukan penjaminan kualitas (mutu) lemdik ASN di seluruh Indonesia melalui proses akreditasi untuk lembaga pendidikan dan pelatihan pemerintah (PerKalan 25 Tahun 2015). Proses akreditasi ini dilakukan kepada lembaga pelatihan penyelenggara pelatihan dasar, lembaga penyelenggara pelatihan manajerial, dan lembaga penyelenggara pelatihan teknis. Jika dilihat dari sisi jumlah, belum semua lembaga pelatihan pemerintah terakreditasi, data dari Pusat Pembinaan Pengembangan Kebijakan dan Program Pengembangan Kompetensi ASN (P3K Bangkom ASN) Tahun 2019 menunjukkan bahwa akreditasi untuk lembaga penyelenggara pelatihan dasar baru sebesar $61,6 \%$, sementara akreditasi untuk lembaga penyelenggara pelatihan manajerial baru sebesar 64,4\% (P3K Bangkom ASN, 2019). Kondisi ini menunjukkan bahwa secara kuantitas, penjaminan mutu belum memenuhi proporsi yang dibutuhkan untuk mempercepat peningkatan kompetensi ASN baik untuk lembaga pelatihan dasar ataupun lembaga pelatihan manajerial. Meskipun data lembaga diklat yang terakreditasi bukan merupakan satu-satunya indikator untuk mempercepat peningkatan kompetensi ASN, tetapi mengingat pentingnya peran lemdik dalam pengembangan kompetensi ASN, kondisi ini menunjukkan bahwa dari sisi teknis masih terdapat banyak lembaga pelatihan yang belum terakreditasi yang akan berimplikasi kepada pengembangan kompetensi ASN.

Secara lebih rinci, data P3K Bangkom ASN menunjukkan bahwa hasil lembaga pelatihan terakreditasi yang memperoleh nilai A hanya sebesar $49,4 \%$ untuk pelatihan dasar dan 38,8\% untuk pelatihan manajerial (P3KBangkom ASN, 2019). Hal ini menunjukkan bahwa kegiatan akreditasi yang dilakukan dengan instrumen penilaian sesuai Peraturan Kepala LAN No. 25 Tahun 2015 belum dapat dicapai dengan optimal oleh seluruh lembaga pelatihan karena akreditasi merupakan acuan dominan dalam pemberian ijin penyelenggaraan diklat (P3K Bangkom ASN, 2019). Lebih lanjut, data P3K Bangkom ASN (2019) menunjukkan bahwa semua lemdik yang akreditasi mendapatkan catatan tindak lanjut yang cukup signifikan untuk dilakukan perbaikan, terutama pada sisi perencanaan kualitas tenaga kediklatan. Selain itu, dari sisi sistem penjaminan mutu sebagian besar lemdik belum menjadikan penjaminan mutu sebagai habit dan cenderung menjadikan sebagai pemenuhan administratif dalam proses akreditasi. Penelitian Pertiwi (2019) menyebutkan bahwa eksistensi Komite Penjamin Mutu (KMP) yang merupakan salah satu subunsur dari unsur organisasi lembaga pelatihan belum cukup optimal karena keberadaannya tidak disertai indikator kinerja serta belum adanya model mutu khusus untuk penjaminan mutu diklat. Lebih lanjut penelitian tersebut menemukan bahwa keberadaan KMP di lembaga pelatihan sering kali dibentuk hanya sebagai syarat pengajuan akreditasi. Data akreditasi P3K Bangkom ASN (2019) juga menemukan bahwa hampir semua lemdik yang diakreditasi memiliki surat keputusan (SK) pembentukan tim KMP, namun tidak memiliki atau belum menjalankan pedoman kerja, instrumen penilaian, dan laporan kerja. Kondisi tersebut tentu saja tidak sejalan dengan tujuan LAN ketika memasukkan elemen KMP pada subunsur penilaian akreditasi pelatihan. 
Masalah-masalah yang muncul terkait akreditasi lemdik tersebut menimbulkan pertanyaan bagaimana penjaminan mutu dilaksanakan saat ini dan bagaimana hasilnya? Proses penjaminan mutu yang akan dilihat adalah proses penjaminan mutu seluruh lemdik pemerintah di Indonesia yang meliputi lemdik kementerian, lemdik Lembaga dan lemdik pemerintah daerah. Pemahaman terhadap model penjaminan mutu dan juga hasilnya akan memberikan gambaran mengenai efektifitas pelaksanaan penjaminan mutu dan upaya perbaikan yang harus dilakukan. Studi ini akan menganalisis pelaksanaan penjaminan mutu dan hasilnya untuk melihat instrumen dan proses akreditasi dapat menggambarkan kualitas penyelenggaraan pelatihan dan penjaminan mutu lemdik. Studi juga hanya berfokus pada penjaminan mutu pelatihan dasar dan pelatihan manajerial.

\section{B. METODE PENELITIAN}

Penelitian ini merupakan studi literatur yang menggunakan metode deskriptif kualitatif untuk mengetahui dan menganalisis kondisi faktual penjaminan mutu pada lembaga pelatihan di Indonesia. Menurut Creswell (2014) penelitian kualitatif merupakan jenis penelitian yang mengeksplorasi dan memahami makna di sejumlah individu atau sekelompok orang yang bersal dari masalah sosial. Masalah yang akan diangkat disini adalah permasalahan-permalahan terkait dengan proses penjaminan mutu lembaga pelatihan. Dengan pendekatan kualitatif, maka permasalahan tersebut akan dapat dieksplorasi secara mendalam.

Pengambilan data dalam penelitian ini secara prinsip menggunakan Teknik FGD wawancara dan telaah dokumen untuk memaksimalkan data sekunder sebagai sumber informasi utama penelitian. Data-data sekunder terkait praktik penjaminan mutu lembaga pelatihan yang direkam oleh P3K Bangkom ASN, selain itu juga berbagai laporan penyelenggaran diklat, informasi dari website SIPKA (Sistem Informasi Pengembangan Komptensi ASN), kebijakan atau peraturan perundangan yang relevan dengan implementasi penjaminan mutu pelatihan dipilih secara selektif yang menjadi referensi utama dalam tulisan ini. Dengan menggunakan berbagai dokumen dan data-data terkait proses akreditasi lemdik pemerintah, berbagai data akreditasi Tahun 2018-2019 dilakukan kategorisasi, klasifikasi, dan juga summary untuk menjelaskan berbagai fenomena dan juga kecenderungan dalam proses akreditasi.

Penjaminan mutu lembaga pelatihan oleh beberapa lembaga pelatihan, baik dari sisi praktek penyelenggaraan maupun dari kebijakan ditelaah dengan menggunakan pisau analisis sistem manajemen mutu dari TQM, untuk menemukan beberapa kata kunci dalam pelaksanaan penjaminan mutu di lembaga pelatihan di Indonesia yang menjadi kesimpulan studi ini.

\section{KERANGKA TEORI}

Paradigma New Service Management dalam keilmuan administrasi publik atau yang lebih dikenal dengan penedekatan New Public Service dimulai dengan premis bahwa fokus manajemen publik haruslah warga negara, komunitas dan masyarakat sipil (Robinson, 2015: 10). Tuntutan kualitas, memastikan produk dan jasa sesuai dengan keinginan dan memberikan kepuasan pada pelanggan, menjadi agenda semua kegiatan penyelenggaraan pemerintahan, tidak terkecuali dalam penyelenggaraan pengembangan kompetensi. Hal ini sejalan dengan konsepsi Total Quality Management yang didefinisikan sebagai pendekatan total sebuah organisasi untuk memenuhi kebutuhan pelanggan dan harapan yang melibatkan semua manajer dan karyawan dalam menggunakan metode kuantitatif untuk meningkatkan secara terus menerus proses, produk, dan layanan organisasi (Psychogios dan Priporas, 2007). 
Elemen dasar kualitas dalam Total Quality Management terdiri atas metrologi, standardisasi, akreditasi, sertifikasi dan kontrol pasar. Secara historis kualitas dikembangkan sesuai dengan perkembangan masyarakat. Secara analogi, berevolusi begitu juga dengan unsur-unsur kualitas (Moracanin, 2012:201) TQM menjadi masalah kritis tidak hanya di bidang manufaktur, tetapi juga dalam perawatan kesehatan, pelayanan, organisasi nirlaba dan setiap organisasi lainnya (Kim, 2020:2). TQM menarik perhatian yang semakin besar di sektor publik di mana pemerintah merasa harus berbuat lebih banyak dengan sumber daya yang lebih sedikit. Pemerintah dihadapkan pada kondisi dilematis antara tuntutan warga terhadap pelayanan yang tinggi serta anggaran yang terbatas.

Paradigma baru New Service Management berimplikasi pada reorientasi tools dan teknik dalam TQM. '...They have long planning cycles and put the emphasis on designing quality into their products and into ensuring that attention is paid to their employee attitudes and relationships' (Sallis, 2002:9). Dua hal penting dalam mewujudkan barang dan jasa yang berkualitas adalah mendesain kualitas dalam semua jasa/produk yang dihasilkan serta memastikan semua pegawai memiliki komitmen terhadap kualitas jasa/produk secara berkelanjutan. Mirza (2018:2-3) juga menyebutkan arti penting aspek manusia dalam lingkungan organisasi yang sangat dinamis yaitu kekuatan pengaruh (dengan kata lain leadership yang tepat untuk dapat memengaruhi semua komponen dalam organisasi), komitmen pegawai, hubungan kerja tim baik dan saling mempercayai, assertive communication, voicing out, emotional intelligence dan juga menjaga mindset tim dalam melaksanakan pekerjaan.

Konsep dan prinsip soft side of quality dalam TQM, dalam proses penjaminan mutu diterjemahkan ke dalam berbagai parameter dan indikator untuk mengukur proses penjaminan mutu yang dilakukan. Psychogios \& Priporas (2007:44) menyebutkan sembilan konsep soft TQM yang sering kita jumpai dalam literatur yaitu total employee involvement, continues improvement, continues training, teamwork, empowerment, top-management commitment and support, democratic management style, customer/citizen satisfaction and culture change. Sembilan kriteria ini juga diadopsi dan diadaptasi oleh European Foundation for Quality Management (EFQM) menjadi The EFQM Business Excellence Model (BEM) yang membagi sembilan kriteria ke dalam dua kelompok (Pimentel \& Major, 2016:999). Hal yang sama juga dikemukakan Johnson (2018:41) bahwa keberhasilan penerapan TQM biasanya diukur dari kualitas barang/jasa yang dihasilkan dan juga keberhasilan kontrol atau monitoring kinerja untuk menjamin kualitas barang/jasa, untuk mendapatkan hasil yang baik pada kedua aspek tersebut dibutuhkan committee approach to management, pemberdayaan pegawai, dan juga partisipasi manajemen dalam keseluruhan proses. Sistem manajemen pada TQM berfokus orang/tenaga kerja, sehingga keterlibatan semua orang dalam organisasi, kerja tim, dan pemberdayaan menjadi kunci untuk menjamin kualitas produk/jasa. Semua orang memiliki peran dalam rantai produksi barang/jasa, pelibatan semua orang akan menciptakan keterbukaan arus informasi dan dibarengi dengan kerja sama tim akan menciptakan hubungan kerja dan pembagian tugas yang fair dalam pelaksanaan tugas.

Dalam era yang sangat penuh dengan ketidakpastian dan perubahan yang sangat cepat, semua organisasi dituntut untuk meningkatkan dan memperbaiki kinerjanya. Continuous improvement menjadi penting dan menjadi ciri khas TQM dengan fokus pada pendekatan masalah secara kolaboratif (collaboratively) dan kesesuaian dengan budaya organisasi (culturally) (Adeoti, 2012:118). Kesesuaian dengan budaya organisasi menjadi sangat penting karena organisasi kita adalah sebuah society, '... it is held together by the shared beliefs and values that are deeply embedded in the personalities of the society's members' 
(DeFeo, Joseph A., 2014:27). Norma-norma dalam organisasi ini sangat kuat dan memengaruhi berbagai tindakan dan perilaku orang-orang di dalamnya, dalam hal ini sangat memengaruhi implementasi budaya kualitas dalam organisasi.

Perubahan membutuhkan continuous improvement, juga berimplikasi pada perubahan kompetensi. Peningkatan kualitas sumber daya manusia melalui continuous learning dapat memenuhi tuntutan perubahan kompetensi karena keunggulan kompetitif organisasi terletak pada keterampilan dan kemampuan sumber daya organisasi tersebut (Wickramasinghe dan Gamage dalam, Dubey et al., 2015: 1464). Upaya perubahan yang diarahkan pada sumber daya dapat dilakukan dengan memberikan kesempatan belajar dan mempraktikkan keterampilan baru. Peningkatan pengetahuan, keterampilan, dan motivasi kerja sumber daya akan membawa kesuksesan organisasi (Pambreni et al., 2019:1399). Oakland (dalam Psychogios \& Priporas, 2007:46) menyebutkan bahwa pengembangan kompetensi (pelatihan) yang berkualitas harus berkelanjutan untuk memenuhi tidak hanya perubahan dalam teknologi, tetapi juga perubahan yang melibatkan lingkungan di mana organisasi beroperasi, strukturnya, dan yang paling penting adalah orang yang terlibat di sana. Pengembangan kompetensi yang berkelanjutan dan menjadi budaya dalam organisasi menjadi kunci utama menjawab tantangan perubahan dan juga tuntutan kualitas dalam pemenuhan kebutuhan barang/jasa. Transformasi ke dalam budaya kualitas adalah sebuah proses perubahan, dan proses perubahan mewujudkan budaya kualitas membutuhkan transformasi besar dalam organisasi. Berbagai literatur menyebutkan kebutuhan kepemimpinan dengan komitmen dan dengan semua kewenangan yang dimiliki agar memberikan support dalam mencapai tujuan perubahan.

Perubahan peran pemimpin sangat diperlukan untuk memberikan atau menetapkan tujuan dan sasaran perubahan, dan bagaimana mereka menggunakan sumber daya organisasinya (DeFeo, Joseph A., 2014:35). Kejelasan arah dan juga kinerja yang diharapkan sebagai sebuah komitmen pemimpin akan mempermudah semua anggota memahami tanggung jawab dan ukuran kinerjanya. Kepemimpinan mengacu pada bagaimana pemimpin membimbing, mengawasi dan mengendalikan sumber daya organisasi dengan cara yang tepat untuk mencapai tujuan TQM (Dubey et al., 2015:1464). Dan sebagai konsekuensi komitmen pimpinan/manajer ini diterjemahkan dengan dukungan sumber daya yang dibutuhkan untuk mencapai tujuan perubahan yang diinginkan. Selain dukungan sumber daya, bentuk lain dukungan yang dibutuhkan adalah management style. Crosby (dalam Psychogios \& Priporas, 2007:46) menyebutkan bahwa management style yang dibutuhkan dalam TQM adalah suatu pendekatan, mekanisme dan hubungan kerja yang partisipatif, demokratif dan terbuka. Dengan pendekatan yang humanistis dan pemberdayaan yang tepat, pegawai akan memiliki komitmen dan integritas yang kuat dalam melaksanakan tugas.

Ujung akhir dari TQM adalah kepuasan pelanggan, kepuasan pelanggan adalah tujuan utama semua proses pengelolaan kualitas dari perencanaan kualitas, penjaminan kualitas, dan kontrol kualitas. Organisasi harus mengidentifikasi kebutuhan pelanggan saat ini dan di masa depan, memenuhi persyaratan pelanggan dan berusaha untuk melebihi harapan pelanggan karena setiap organisasi bergantung pada pelanggan (Evans dalam Pambreni et al., 2019). Kepuasan pelanggan dicerminkan dengan kesesuaian pemenuhan kebutuhan publik, mampu membangun hubungan atas dasar saling percaya, proses kolaboratif dalam pemenuhan kebutuhan pelanggan, kesesuaian dengan aturan dan norma serta budaya, memberikan pelayanan bukan mengatur (serve rather than steer), dan memberikan nilai dan menghargai pelanggan (Denhardt, Janet J., 2007:43). Wen et al. dan Letica dalam (AlQahtani et al., 2015:122) juga mengklarifikasi dampak praktik TQM terhadap tingkat kepuasan pelanggan khususnya di sektor pelayanan publik dan dari sudut pandang manajer. 
Fokusnya adalah perencanaan secara strategis, manajemen proses dan karyawan, kepemimpinan, kepedulian pelanggan, dan pengukuran tingkat kepuasan pelanggan internal dan eksternal atas kualitas produk dan layanan yang dirasakan. Penelitian ini menunjukkan bahwa ada hubungan positif antara praktik TQM, fokus karyawan dengan tingkat kepuasan pelanggan. Dengan demikian TQM adalah sebagai suatu sistem yang dilaksanakan dalam jangka panjang dan terus menerus untuk memuaskan penerima layanan dengan meningkatkan kualitas produk layanannya. Sehingga dengan demikian sasaran yang ingin dicapai dari peningkatan kualitas produk adalah kepuasan penerima layanan.

Total Quality Management (TQM) melibatkan pemahaman dan implementasi prinsipprinsip dan konsep manajemen mutu dalam seluruh aspek kegiatan bisnis. TQM menuntut prinsip-prinsip manajemen mutu harus diterapkan dalam setiap level, setiap tahapan, setiap unit dalam sebuah organisasi (Dahlgaard, Jens J., 2005:8). Penjaminan Mutu perlu memotret keseluruhan implementasi prinsip-prinsip TQM dalam pelaksanaannya. Terdapat empat dimensi kegiatan penjaminan mutu yaitu struktur (proses dan penilaian hasil), tinjauan kongruen vs retrospektif, tinjauan internal vs eksternal, dan juga penilaian individu vs penilaian agregat (William, T., 1984:4). Manajemen perlu memastikan bahwa semua rencana dan juga pekerjaan dilakukan untuk menghasilkan barang/jasa yang berkualitas (Quality Assurance) dengan menggunakan berbagai sumber daya yang dimiliki. Quality assurance is about designing quality into the process to attempt to ensure that the product is produced to a predetermined specification (Sallis, 2002:17). Jika quality control dilakukan untuk memastikan produk/jasa sudah memenuhi spesifikasi produk final, kegiatan quality assurance dilakukan pada sebelum dan selama proses produksi barang/jasa berlangsung untuk mencegah dan memperbaiki kesalahan sedini mungkin. Konteks ini membutuhkan apa yang disebut sebagai hard side of quality.

Penyusunan hard side dari TQM memerlukan peranan penting dari teknik manajemen, alat, dan sistem. Goetsch dan Davis (2014:258) mendefinisikan alat manajemen sebagai sarana untuk menyelesaikan masalah, meningkatkan pengambilan keputusan, melacak pekerjaan yang sedang dilakukan, dan bahkan memprediksi kinerja dan masalah di masa depan. Sejumlah literatur dari TQM menyediakan berbagai alat, teknik, dan sistem manajemen mutu. Digital Disruption dewasa ini telah mengubah strategi organisasi dalam hard side of quality, khususnya terkait transformasi digital dalam pengelolaan organisasi (baik secara proses atau pun teknologi). Transformasi teknologi dalam pengelolaan diklat untuk meningkatkan efisiensi dan dan efektifitas dalam menciptakan kepuasan publik. Power dan Heavin (2018:2) menyebutkan bahwa berbagai aktivitas dalam organisasi, baik proses pengambilan keputusan atau proses harus responsif terhadap kebutuhan dan juga lingkungan yang menuntut kecepatan dalam pembuatan keputusan. Lebih lanjut mereka mengatakan bahwa tidak cukup hanya memahami kebutuhan akan teknologi baru untuk mendukung proses, tetapi bagaimana menggunakannya dalam pengambilan keputusan dan juga kemungkinan perbaikan atau perubahan dalam prosesnya untuk perubahan ke arah yang lebih baik (Power dan Heavin, 2018:2-3).

Dalam beberapa studi tentang penjaminan mutu diklat, prinsip TQM juga muncul dalam beberapa sudut pandang, walaupun tidak secara eksplisit, seperti dari Witesman, E. M., \& Wise, C. R (2009:116) yang menganalisis mengenai mutu pelatihan, melakukan uji hipotesis mengenai pilihan pendekatan sentralistik atau desentralisasi dalam pelaksanaan pelatihan bagi pegawai negeri berpengaruh terhadap kemampuan menghasilkan nilai dan keterampilan. Hasil studi mereka di Ukraina menunjukkan bahwa pendekatan terpusat lebih mampu mendorong pelatihan yang berkualitas. Walaupun demikian, studi ini terbatas pada konteks Ukraina yang dari struktur pemerintahan dan kultur birokrasi lebih sesuai pada 
pendekatan satu komando. Studi ini mengindikasikan bahwa uniformitas menjadi salah satu kunci dalam menjaga mutu pelatihan. Sebaliknya dari sudut pandang konten pelatihan, tulisan Johnstone, R. (2018:1) tentang pelatihan pegawai negeri di Inggris, tema sentralisasi cenderung dihindari dan justru pegawai negeri justru didorong untuk mengikuti pelatihan devolusi sebelum memulai bekerja di birokrasi. Dalam tulisan lain dari Smith (2018:1) yang menjelaskan bahwa pemerintah Inggris juga tidak akan memberikan pelatihan tambahan, khususnya terkait keamanan saiber di luar yang sudah diwajibkan. Hal ini dilakukan untuk memastikan mutu pelatihan yang lebih menemui sasaran dengan strategi pelatihan yang tidak memberikan beban tambahan, baik dari sisi penyelenggara maupun bagi pegawai negeri sebagai peserta pelatihan itu sendiri. Merujuk pada sumber-sumber ini, maka dari sisi nilai terdapat perbedaan cara pandang dalam penyelenggaraan pelatihan di kedua negara, yang tentunya dipengaruhi oleh perbedaan kultur birokrasi.

Sebuah penelitian yang berfokus pada manajemen mutu pelatihan di dalam negeri oleh Susanto (2010:v) dalam studinya mengenai penerapan pendekatan manajemen ISO 90012008 dalam strategi manajemen mutu pendidikan dan latihan dengan menemukan bahwa untuk membangun sistem penyelenggaraan diklat harus konsisten terhadap pedoman mutu yang telah ditetapkan, prosedur mutu, kebijakan mutu dan sasaran mutu. Selain itu terdapat delapan prinsip manajemen mutu yang merupakan indikator yang dilakukan untuk menilai apakah sistem manajemen mutu yang diterapkan adalah efektif dengan dilakukan audit internal secara berkala setiap enam bulan sekali. Terakhir, sistem manajemen mutu ISO 9001-2008 merupakan indikator proses implementasi manajemen mutu di organisasi dengan pendekatan TQM dan PDCA yang telah banyak diterapkan organisasi dan institusi pendidikan di seluruh dunia. Ini berarti bahwa faktor konsistensi penyelenggara diklat dalam menjalankan seluruh pedoman mutu menjadi kunci bagi sebuah diklat yang berkualitas. Keberadaan pedoman mutu tidak akan menjamin mutu yang lebih baik selama penyelenggara tidak menjalankannya secara konsisten. Di samping itu, konsistensi ini juga termasuk di dalamnya adalah pelaksanaan audit yang dilakukan secara rutin, serta penggunaan indikator manajemen mutu.

Konsep TQM umum dipakai pada sektor manufaktur meski beberapa waktu ke belakang sudah mulai banyak diadopsi di sektor pemerintahan, namun literatur yang membahas penerapan TQM di lembaga pelatihan pemerintah masih sangat terbatas. Para pendukung kualitas tanpa syarat akan berpendapat bahwa TQM dapat diimplementasikan di sektor publik, namun para pegawai negeri tidak cepat mengadopsi konsep ini. Pada prinsipnya PNS jelas melihat manfaatnya tetapi tetap ingin melihat kasus konkret implementasinya di sektor publik. Lembaga pelatihan pemerintah memiliki posisi yang strategis sebagai salah satu wadah untuk mengembangkan kompetensi ASN terutama melalui pelatihan dasar dan pelatihan manajerial. Penerapan TQM dalam melihat proses penjaminan mutu lembaga pelatihan tidak hanya mengembangkan pendekatan pelatihan dan pendidikan yang inovatif untuk TQM di sektor publik, tetapi juga meningkatkan kualitas pemberian layanan kepada masyarakat.

\section{HASIL DAN PEMBAHASAN}

Proses penjaminan kualitas pelaksanaan pelatihan ASN di Indonesia dilaksanakan oleh Lembaga Administrasi Negara (LAN). Sesuai dengan Peraturan Pemerintah (PP) Nomor 101 Tahun 2000 Tentang Pendidikan Dan Pelatihan Jabatan Pegawai Negeri Sipil), LAN merupakan instansi pembina yang bertanggung jawab atas pembinaan pendidikan dan pelatihan secara keseluruhan. Pembinaan di sini diartikan sebagai pengaturan, koordinasi dan penyelenggaraan diklat. Salah satu bentuk pembinaan adalah akreditasi, yang bertujuan 
untuk memberikan penjaminan kualitas penyelenggaraan diklat. Pelaksanaan akreditasi diatur dengan Peraturan Kepala (Perka) LAN No. 25 Tahun 2015 tentang Pedoman Akreditasi Lembaga Diklat (lemdik) Pemerintah. Pasal 1 (2) Ketentuan Umum menyebutkan bahwa akreditasi lemdik adalah penilaian kelayakan lemdik dalam menyelenggarakan Diklat Prajabatan, Diklat Kepemimpinan, Diklat Teknis, dan Diklat Fungsional yang ditetapkan dalam surat keputusan dan sertifikat akreditasi oleh instansi pembina.

Saat ini terdapat sekitar 270 lembaga pelatihan yang menyelenggarakan Diklat Latsar dan Manajerial masing-masing pada tabel 1 dan 2:

Tabel 1.

Data Sebaran Lembaga Pelatihan di Indonesia

\begin{tabular}{lcc}
\hline & $\begin{array}{c}\text { Jumlah Lembaga } \\
\text { Pelatihan Penyelenggara } \\
\text { Latsar }\end{array}$ & $\begin{array}{c}\text { Jumlah Lembaga Pelatihan } \\
\text { Penyelenggara Manajerial }\end{array}$ \\
\hline Kementerian & 80 & 75 \\
LPNK & 16 & 15 \\
Provinsi & 34 & 34 \\
Kabupaten/Kota & 8 & 8 \\
$\quad$ Total & 138 & 132 \\
\hline
\end{tabular}

Sumber: P3K Bangkom ASN, 2020

Hingga tahun 2019, LAN telah melakukan akreditasi terhadap 85 (61,59\%) lemdik penyelenggara latsar, dengan persentase pelaksanaan akreditasi tertinggi pada lemdik Tingkat Provinsi sebanyak 88,24\% dan terendah pada kabupaten/kota sebanyak $25 \%$.

Tabel 2.

Sebaran Lembaga Pelatihan Penyelenggara Pelatihan Dasar

Jumlah Lembaga Jumlah Lembaga \%

Pelatihan Penyelenggara Pelatihan

Latsar Terakreditasi

\begin{tabular}{lccr}
\hline Kementerian & 80 & 41 & 51,25 \\
LPNK & 16 & 12 & 75 \\
Provinsi & 34 & 30 & 88,2352941 \\
Kabupaten/Kota & 8 & 2 & 25 \\
\multicolumn{1}{c}{ Total } & 138 & 85 & 61,5942029 \\
\hline
\end{tabular}

Sumber: P3K Bangkom ASN, 2020

Hasil yang relatif sama juga diperoleh dalam akreditasi Penyelenggara Pelatihan Manajerial. Jumlah lembaga pelatihan yang telah terakreditasi dalam pelatihan manajerial sebanyak $64,39 \%$ dengan persentase tertinggi pada tingkat provinsi $(88,24 \%)$ dan terendah berada di kabupaten/kota sebesar 37,5\%. 
Tabel 3.

Sebaran Lembaga Pelatihan Penyelenggara Pelatihan Manajerial Jumlah Lembaga Jumlah Lembaga $\%$

Pelatihan Penyelenggara

Pelatihan

Manajerial

Terakreditasi

\begin{tabular}{rccc}
\hline Kementerian & 75 & 42 & 56,00 \\
LPNK & 15 & 10 & 66,67 \\
Provinsi & 34 & 30 & 88,24 \\
Kabupaten/Kota & 8 & 3 & 37,50 \\
Total & 132 & 85 & 64,39 \\
\hline
\end{tabular}

Sumber: P3K Bangkom ASN, 2019

Penilaian terhadap akreditasi menggunakan instrumen yang terdiri atas dua unsur, yaitu Organisasi Lemdik dan Program dan Pengelolaan Program Diklat. Unsur organisasi terdiri atas subunsur kelembagaan diklat, tenaga kediklatan, rencana strategis, penjaminan pembiayaan, fasilitas diklat dan penjaminan mutu. Sedangkan dari unsur program diklat dan manajemen (pengelolaan) program diklat terdiri dari kurikulum program dan pengelolaan (perencanaan, penyelenggaraan, monitoring dan evaluasi) program diklat. Gambaran mengenai unsur dan subunsur serta masing-masing pembagian persentase dapat dilihat pada gambar 1.
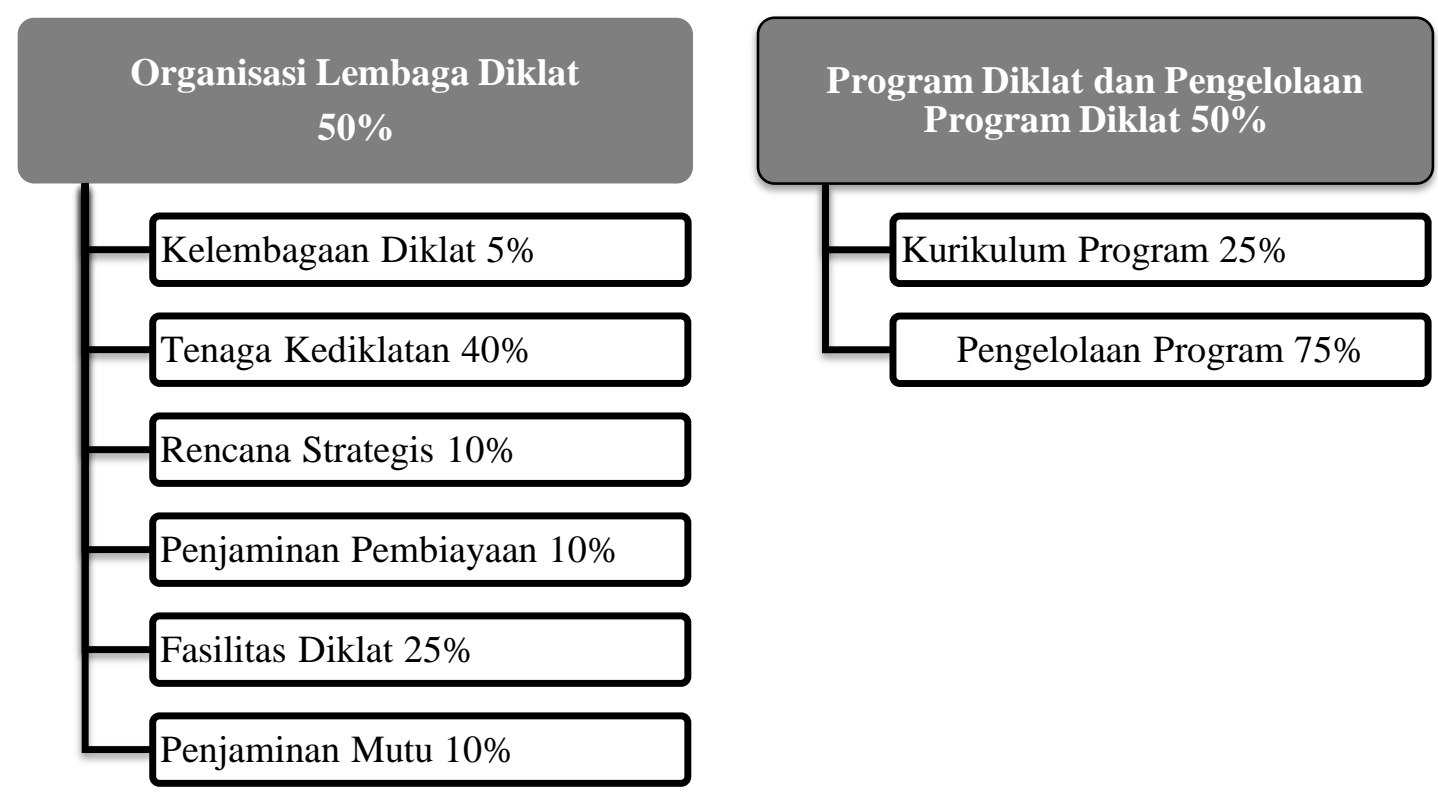

\section{Gambar 1.}

Unsur dan Sub Unsur Akreditasi (Sumber: P3K Bangkom ASN, 2019)

Desain instrumen penjaminan kualitas sebagaimana digambarkan di atas menunjukkan bahwa LAN sudah mendesain sebuah sistem untuk memastikan kualitas, baik dari sisi kelembagaan dan juga pengelolaan program pelatihan, lebih rinci hal ini diatur di dalam Perkalan Nomor 25 Tahun 2015. Sistem ini digunakan untuk memastikan bahwa struktur organisasi, tanggung jawab, prosedur, proses, dan sumber daya (termasuk manusia) dikelola 
sehingga menghasilkan pelayanan diklat sesuai yang dibutuhkan oleh pelanggan. Aspek manusia dalam lingkungan organisasi memiliki arti yang sangat penting, leadership yang tepat dapat memengaruhi semua komponen dalam organisasi, komitmen pegawai, hubungan kerja tim baik dan saling mempercayai, assertive communication, voicing out, emotional intelligence dan juga menjaga mindset tim dalam melaksanakan pekerjaan (Mirza, 2018:23). Mengingat pentingnya aspek sumber daya manusia ini, persentase yang besar juga diberikan pada subunsur tenaga kediklatan (40\%). Hal ini bertujuan untuk memastikan bahwa semua sumber daya manusia pegawai yang dimiliki lemdik memiliki komitmen terhadap kualitas Jasa Pelatihan. Namun jika ditilik lebih dalam komponen dalam subunsur tenaga pelatihan, indikator dan data-informasi yang digunakan untuk menilai subunsur ini cenderung bersifat statis dan menitikberatkan pada berbagai persyaratan untuk menjalankan tanggung jawab dari masing-masing sumber daya manusia. Pemenuhan terhadap persyaratan menjadi penting untuk memastikan sumber daya manusia memiliki kompetensi untuk melaksanakan pekerjaan/tanggung jawab, tetapi yang tidak kalah penting adalah memastikan bahwa kompetensi tersebut digunakan untuk melakukan pekerjaan (berkinerja) sehingga menghasilkan produk yang berkualitas.

Untuk mempertahankan peningkatan dan pertumbuhan jangka panjang, keberadaan sumber daya utama organisasi yang berupa people, systems dan procedures, sangat ditentukan pada kemampuan sumber daya manusia, loyalitas dan kepuasannya serta pengembangan kompetensi (Kolibáčová, 2014:1316). Dari hasil survei pelaksanaan diklat (Pusbangkom TSK-LAN, 2019) ditemukan bahwa berbagai indikator yang digunakan dalam unsur tenaga kediklatan belum mampu memotret berbagai informasi terkait loyalitas dan kepuasan sumber daya manusia penyelenggara pelatihan. Masih banyak terdapat catatancatatan dari peserta pelatihan untuk tenaga kediklatan yang belum terakomodir di dalam instrumen tenaga kediklatan yang sudah ada. Sedangkan aspek kemampuan yang dicerminkan dengan keberadaan berbagai persyaratan untuk melaksanakan pekerjaan dan juga pengembangan kompetensi sudah diakomodasi sudah menjadi bagian dari instrumen akreditasi.

Studi yang dilakukan McKinsey menyebutkan bahwa kesuksesan pengelolaan perubahan dalam organisasi untuk mendapatkan kepuasan market (studi ini menggunakan indikator standard market), dan juga relevan untuk organisasi publik, setidaknya harus memastikan semua stakeholder yang terlibat dalam inisiatif harus terlibat dan berhubungan dengan baik; pembagian tanggung jawab yang jelas, baik pada level tim kerja, individu, manajemen maupun juga pemimpin; dan tujuan, visi dan juga outcome yang diharapkan dari inisiasi perubahan harus dipahami dan diterima oleh semua komponen dalam organisasi (Mattingly, 2018:4). Proses akreditasi belum secara komprehensif mengakomodasi indikator keterlibatan stakeholder dalam pengelolaan diklat serta pengambilan keputusan dan juga pengelolaan pembagian tugas antar sumber daya yang dimiliki. Hal ini terlihat dari belum adanya subunsur terkait di dalam Perkalan 25 Tahun 2015 yang mengeksplor lebih jauh tentang keterlibatan stakeholders, pengambilan keputusan dan juga pembagian tugas antar sumber daya. Sedangkan indikator terkait pemahaman dan penerimaan visi dan sasaran organisasi sudah diakomodasi dalam subunsur rencana strategis (lihat Gambar 1).

Jika kita lihat secara detail indikator yang digunakan, hanya subunsur Pengelola Sistem Informasi Diklat yang diarahkan secara langsung untuk memastikan proses dikelola secara rutin. Namun, demikian informasi ini hanya dipantau dan diperoleh pada saat akreditasi (disiapkan dan dicek pada saat akreditasi) sehingga akurasi informasi dalam akreditasi terkait konsistensi dan komitmen juga masih perlu dikaji lebih lanjut. Faktor kepemimpinan yang juga sangat penting dalam penjaminan kualitas juga belum dieksplore 
lebih dalam. Tabel 4 menunjukkan bahwa indikator untuk pengelola diklat (untuk merepresentasikan pemimpin dalam lemdik) dipotret dari sisi persyaratan (administrasi) belum memotret kinerja kepemimpinan. Sebagaimana dikemukakan Bendermacher et al., (2017:47) yang mengutip kajian yang dilaksanakan oleh Flumerfelt dan Banachowski (2011) dan Calvo-Mora et al. (2006) serta Knight and Trowler (2000) bahwa arti penting kepemimpinan dalam menjamin kualitas yakni memengaruhi alokasi sumber daya, mengatur dan mengklarifikasi peran dan tanggung jawab, menciptakan partnerships dan memengaruhi orang dan proses manajemen serta memengaruhi pengembangan dan adopsi budaya mutu organisasi yang sangat penting untuk menciptakan kepercayaan dan saling percaya dalam organisasi. Informasi-informasi ini seharusnya juga dikumpulkan dan dianalisis untuk menunjukkan kinerja dan komitmen pimpinan dalam penerapan TQM.

Dalam Perkalan 25/2015, yang dimaksud dengan SDM atau tenaga kediklatan adalah pengelola pelatihan, penyelenggara pelatihan, tenaga pengajar, pengelola sistem informasi diklat, perancang kurikulum dan penganalisis kebutuhan diklat.

Tabel 4.

Subunsur, Komponen dan Indikator Tenaga Kediklatan

\begin{tabular}{ll}
\hline \multicolumn{1}{c}{ Komponen } & \multicolumn{1}{c}{ Indikator } \\
\hline Pengelola Diklat & $\begin{array}{l}\text { Sertifikat Management of Training (MoT), Sertifikat Diklat } \\
\text { Pim, Pengalaman (kerja) dan Penyelenggara (keterlibatan } \\
\text { dalam pelaksanaan Diklat) }\end{array}$ \\
Penyelenggara Diklat & $\begin{array}{l}\text { Pengalaman (kerja), Sertifikat Training Officer Course } \\
\text { (TOC), Penyelenggara (keterlibatan dalam pelaksanaan }\end{array}$ \\
& $\begin{array}{l}\text { Diklat) } \\
\text { Pengalaman (kerja), Training of Trainer (ToT) Substansi, }\end{array}$ \\
Tenaga Pengajar & $\begin{array}{l}\text { Pengembangan Profesionalisme, Pengalaman (kerja) } \\
\text { Pengelola SIPKA }\end{array}$ \\
& $\begin{array}{l}\text { Pengelolaan informasi diklat secara rutin, lengkap, andal, } \\
\text { bermanfaat, akurat, tepat waktu, dan konsisten pada SIPK; } \\
\text { pemanfaatan sistem informasi diklat internal }\end{array}$
\end{tabular}

Sumber: Diolah dari Perka Lan No. 25/2015.

Keberhasilan penerapan TQM biasanya diukur dari kualitas barang/jasa yang dihasilkan dan juga keberhasilan kontrol atau monitoring kinerja untuk menjamin kualitas barang/jasa, untuk mendapatkan hasil yang baik pada kedua aspek tersebut dibutuhkan committee approach to management, pemberdayaan pegawai, dan juga partisipasi manajemen dalam keseluruhan proses (Johnson, 2018:41). Dari sisi subunsur pengelolaan program yang memiliki komponen rencana penyelenggaraan, penyelenggaraan diklat, monitoring dan evaluasi (Monev) penyelenggaraan, dan hasil penyelenggaraan sudah menunjukkan bahwa pelaksanaan akreditasi mencoba untuk memotret upaya lemdik melakukan kontrol dan jaminan terhadap proses sebelum dan selama pelaksanaan diklat untuk memastikan bahwa penyelenggaraan berjalan dengan baik dan mendapatkan hasil sesuai yang diharapkan. 
Tabel 5.

Subunsur, Komponen dan Indikator Pengelolaan Program

\begin{tabular}{ll}
\hline \multicolumn{1}{c}{ Komponen } & \multicolumn{1}{c}{ Indikator } \\
\hline Rencana Penyelenggaraan & $\begin{array}{l}\text { Dokumen Perenanaan (mis: Renstra), proses penyusunan, } \\
\text { internalisasi serta diseminasinya }\end{array}$ \\
Penyelenggaraan Diklat & $\begin{array}{l}\text { Ketersediaan pedoman dan panduan penyelenggaraan, } \\
\text { master jadwal, persiapan penyelenggaraan (tim pengajar, } \\
\text { narasumber, SDM dll), dan informasi kediklatan }\end{array}$ \\
Monev Penyelenggaraan & $\begin{array}{l}\text { Instrumen dan Hasil Monev serta tindak lanjutnya } \\
\text { Hasil Penyelenggaraan }\end{array}$ \\
& $\begin{array}{l}\text { Hasil diklat/kelulusan, dokumentasi dan diseminasi } \\
\text { proses pembelajaran, pengelolaan alumni }\end{array}$
\end{tabular}

Sumber: Diolah dari Perka LAN No. 25/2015.

Namun demikian, data dan informasi yang diolah dalam proses akreditasi hanya diisi pada saat akan dilaksanakan proses akreditasi. Secara sistem, pelaksanaan akreditasi dimulai dengan a). penginputan berbagai data yang dibutuhkan; b) proses analisis oleh tim asesor, klarifikasi serta penentuan hasil akreditasi; serta output akreditasi penetapan hasil dan pemberian sertifikat hasil.

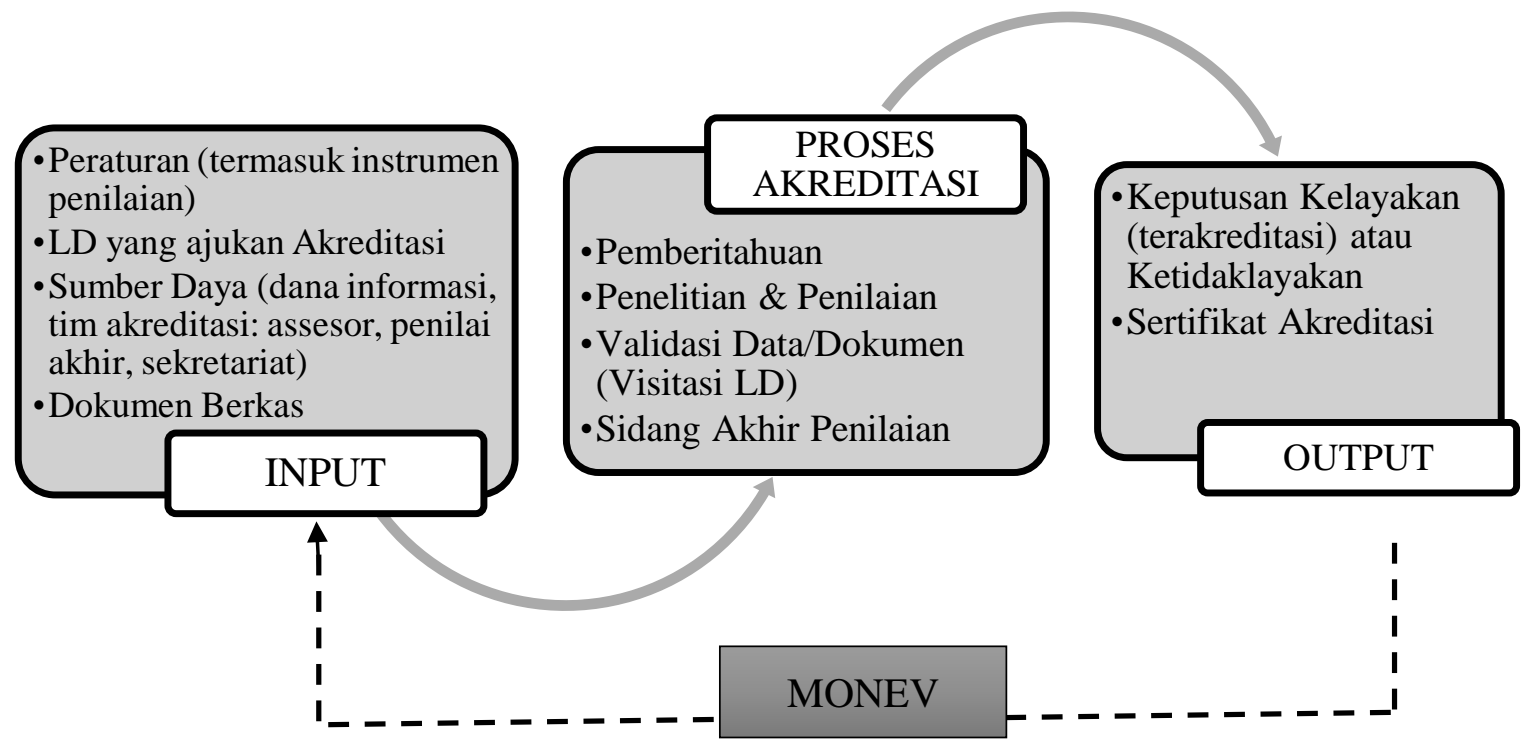

Gambar 2.

Sistem Akreditasi (Sumber: P3K Bangkom ASN, 2019)

Lemdik akan menginput data-data terkait penyelenggaraan diklat sesudah P3K Bangkom-LAN membuka sistem akreditasi (dimulai dengan pemberitahuan formal melalui surat pelaksanaan akreditasi). Lama waktu input sangat tergantung pada kesiapan lemdik menyiapkan berbagai informasi yang dibutuhkan (tidak ada batasan waktu secara formal untuk proses input ini, dalam prakteknya lemdik membutuhkan waktu sekitar 7 sampai dengan 30 hari kerja. Sedangkan sesudah tahapan verifikasi data melalui visitasi, perbaikan dan penambahan data dilaksanakan selama tiga hari kerja. Proses input data hanya dilakukan dalam kerangka pelaksanaan akreditasi, sehingga lemdik hanya menyiapkan dan memberikan informasi selama proses akreditasi. Berbagai data dan informasi hanya 
disiapkan sebagai bagian pemenuhan administrasi akreditasi bukan sebagai sebuah proses yang secara rutin dilakukan untuk memastikan kualitas proses pelaksanaan diklat. Penelitian Pertiwi (2018) menemukan bahwa keberadaan Tim Penjamin Mutu, sering kali hanya disiapkan untuk memenuhi komponen Penjaminan Mutu (10\%) namun belum melakukan fungsinya untuk memastikan perbaikan dan jaminan mutu secara berkelanjutan. Lavagnon et al., (dalam Gomes et al., 2019:215) mengemukakan keberhasilan suatu proyek atau kegiatan sering kali tidak tergantung pada perencanaan, tetapi lebih pada hubungan positif antara penggunaan monitoring dan evaluasi dan dampat proyek/kegiatan dalam jangka Panjang. Hal ini mengindikasikan bahwa monitoring dan evaluasi adalah alat yang efektif untuk continues improvement. Proses akreditasi perlu didesain untuk menjamin pelaksanaan monitoring dan evaluasi dilakukan setiap saat dan tidak hanya dilakukan pada waktu akan dilaksanakan akreditasi.

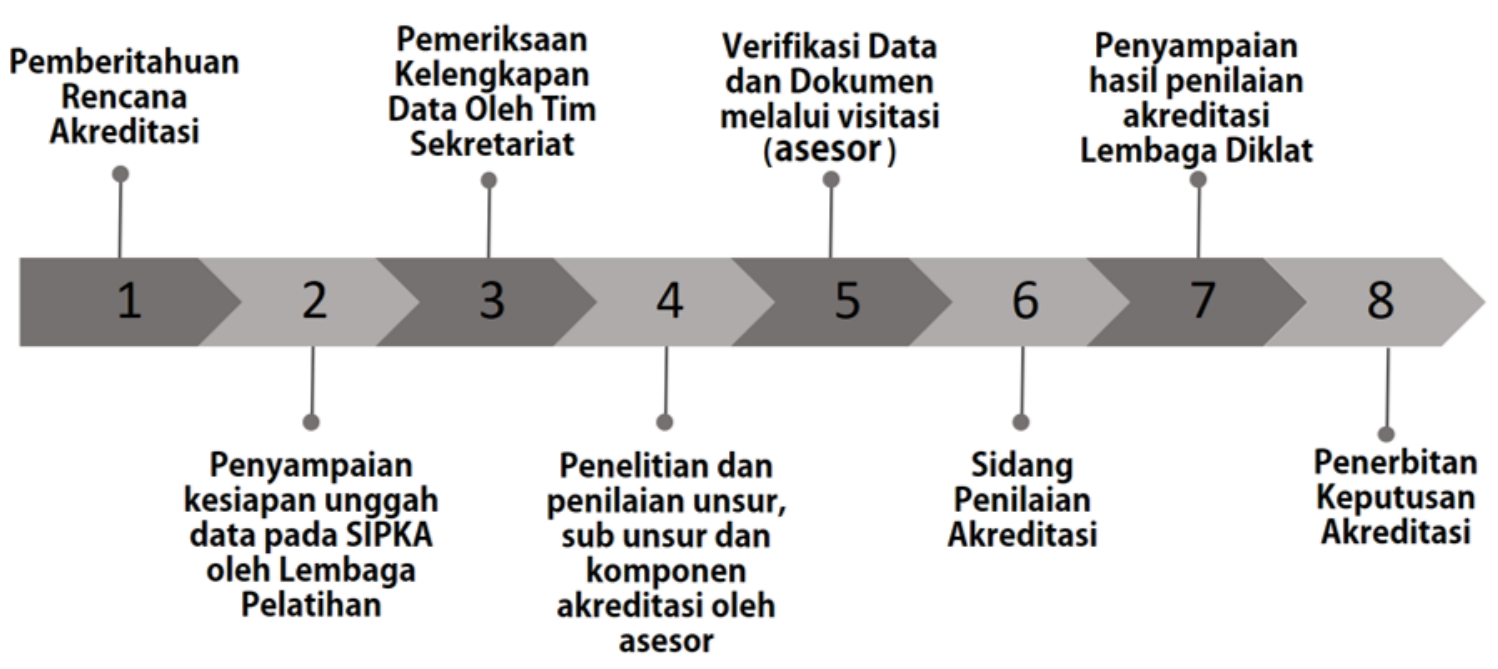

Gambar 3.

Tahapan Pelaksanaan Akreditasi (Sumber: P3K Bangkom ASN, 2019)

Penilaian awal untuk mendapatkan hasil akhir akreditasi (output pelaksanaan akreditasi), dilakukan oleh tim asesor yang terdiri dari tiga orang dan dilaksanakan dengan desk analysis serta verifikasi data-data secara langsung. Hasil ini akan disidangkan untuk mendapatkan hasil akhir berupa kelayakan/ketidaklayakan untuk menyelenggarakan diklat. Lemdik dengan nilai total akreditasinya 71,00 atau lebih dinyatakan layak untuk menyelenggarakan pelatihan bagi ASN (PerkaLAN, 2015). Nilai kelayakan akreditasi terdiri atas kategori: 1) A untuk rentang nilai 91,00 s.d 100 (masa berlaku 5 tahun); 2) B untuk rentang nilai 81,00 s.d 90,99 (masa berlaku 3 tahun); dan $C$ untuk rentang nilai 71,00 s.d 80,99 (masa berlaku 2 tahun). Hasil pelaksanaan akreditasi dapat digambarkan pada grafik 1. 


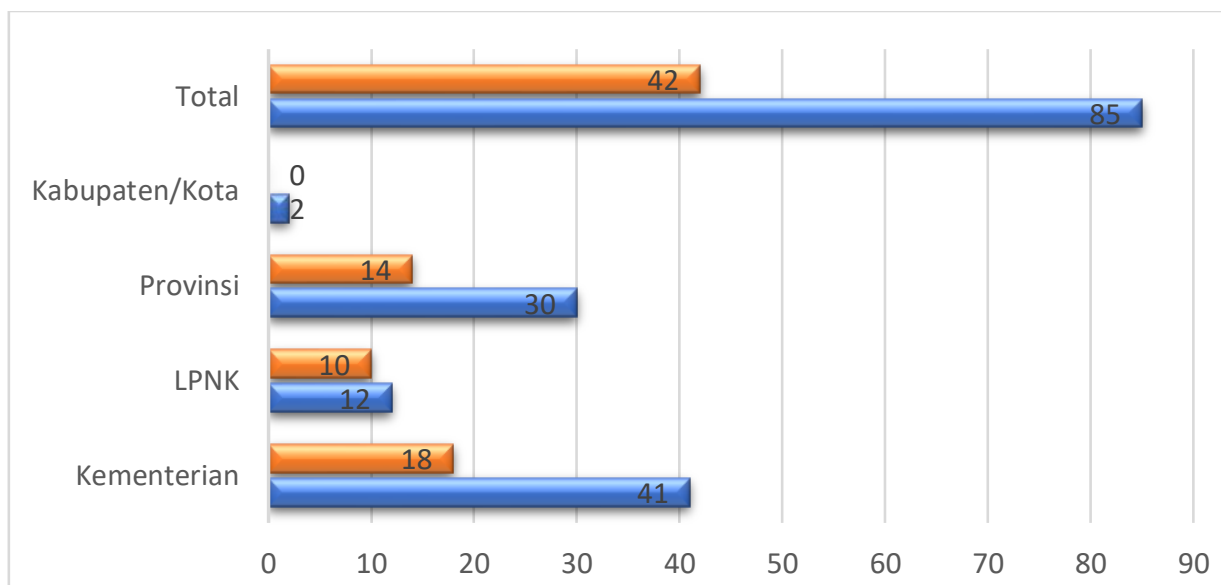

曰 Jumlah Lembaga Pelatihan dengan Nilai A $\mathbf{\square}$ Jumlah Lembaga Pelatihan Terakreditasi

\section{Grafik 1.}

Perbandingan Lembaga Pelatihan Penyelenggara Pelatihan Dasar dengan Nilai A (Sumber: P3K Bangkom ASN, 2019)

Grafik 1 menunjukkan bahwa terdapat 42 lembaga pelatihan penyelenggaraan latsar yang memperoleh nilai akreditasi A dari total 85 lembaga pelatihan yang telah terakreditasi, atau sebesar 49,4\%, dengan jumlah terbanyak pada level kementerian yaitu sebanyak 18 lembaga. Pada Penyelenggara Pelatihan Manajerial terdapat 33 lembaga pelatihan yang mendapatkan akreditasi A dari total 85 lembaga yang sudah terakreditasi, atau sebesar 38,8\% dan jumlah lembaga pelatihan yang terakreditasi A terbanyak juga pada level kementerian yaitu sebanyak 17 lembaga (lihat Grafik 2).

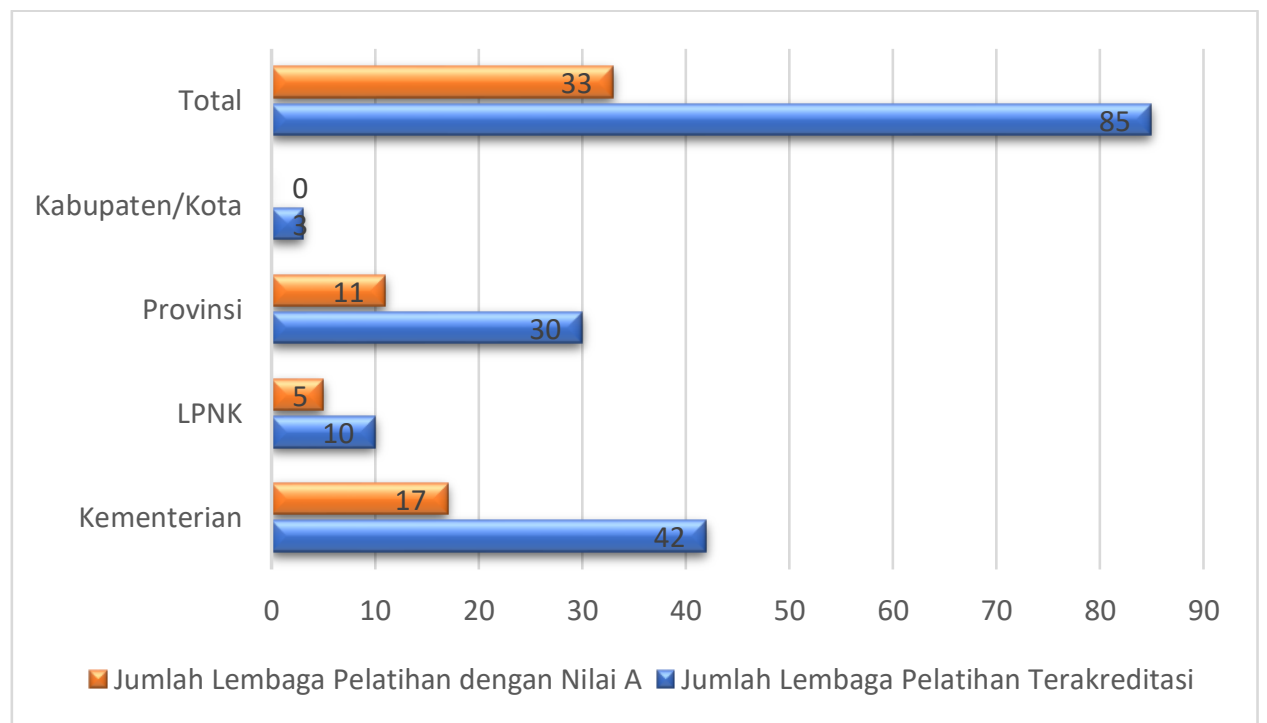

Grafik 2.

Perbandingan Lembaga Pelatihan Penyelenggara Pelatihan Manajerial dengan Nilai A (Sumber: P3K Bangkom ASN, 2019)

Nilai Akreditasi A, baik pada pelatihan Manajerial maupun Latsar memberikan gambaran bahwa proses ini harus selalu didorong agar jumlah lembaga yang memperoleh nilai akreditasi A secara kuantitatif menjadi semakin meningkat. Peningkatan jumlah ini 
memberikan indikasi akan semakin banyaknya lemdik yang telah melakukan penjaminan mutu dalam penyelenggaraan diklat bagi ASN. Selain pemberian predikat berupa nilai yang menunjukkan kelayakan penyelenggaraan diklat dan masa berlaku akreditasi, proses akreditasi juga memberikan catatan-catatan yang harus ditindaklanjuti lemdik untuk peningkatan kualitas penyelenggaraan diklat. Kegiatan penjaminan kualitas melalui akreditasi sudah diarahkan untuk melihat aspek: 1) perencanaan kualitas (untuk memastikan bahwa penjaminan dilakukan pada tahapan perencanaan penyelenggaraan diklat); 2) penjaminan kualitas (penjaminan kualitas pada saat pelaksanaan diklat); 3) kontrol kualitas (penjaminan kualitas atas hasil diklat); 4) peningkatan kualitas (penjaminan kualitas secara berkelanjutan).

Catatan-catatan terkait aspek-aspek tersebut atas 53 lemdik yang diakreditasi pada tahun 2019 dapat dirangkum antara lain dari sisi pelaksanaan penjaminan mutu selama diklat terdapat tiga fokus yaitu dari sisi pelaporan, komunikasi dan evaluasi. Pelaporan bersifat objektif dan professional, monitoring yang dilakukan secara berkala, adanya tindak lanjut monitoring dan evaluasi, serta pelaksanaan monitoring dan evaluasi yang berbasis online. Selain itu terkait upaya komunikasi dalam penyelenggaraan diklat dilakukan oleh penyelenggara dengan fasilitator. Dan sisi evaluasi yang menekankan pada keterlibatan peserta sebagai pemberi input evaluasi.

Dari sudut pandang peningkatan kualitas, maka unsur yang paling menonjol adalah terkait penggunaan teknologi informasi dalam pembelajaran diklat. Beberapa hal yang terkait langsung dalam penggunaan teknologi informasi ini adalah updating data (termasuk dokumentasi online), pengelolaan sistem informasi, penguatan pembelajaran e-learning, serta pembangunan sistem informasi. Unsur selanjutnya yang muncul adalah pelibatan tenaga profesi dalam kegiatan diklat dan pengembangan infrastrukturnya, seperti pelibatan dalam pembelajaran, pembuatan panduan teknis atau pengayaan bahan ajar, termasuk di dalamnya adalah pengembangan profesi dan pengembangan kompetensi.

Unsur yang tak kalah penting dalam peningkatan kualitas adalah kepemimpinan dalam penyelenggaraan diklat, termasuk di dalamnya adalah pelaksanaan koordinasi internal maupun komunikasi dengan stakeholder maupun sisi visioning dan penetapan nilai-nilai dalam organisasi. Hacker dan Washington (2018:xii) menyebutkan bahwa sering kali kompetensi pimpinan dapat dilihat secara langsung seperti dalam mengelola hasil outward results), pengambilan keputusan, dan juga perilaku dalam organisasi, namun kompetensi pimpinan juga dapat dilihat dalam mengelola dirinya (leading self), misalnya dalam penyusunan tujuan, visi, dan mengidentifikasi nilai-nilai dalam organisasi. Secara teknis dalam pelaksanaan akreditasi, faktor kepemimpinan perlu dilihat dalam subunsur Rencana Strategis. Bagaimana peran dan aktifitas yang dilakukan pimpinan dalam penyusunan Rencana Strategis dan ide-ide dalam internalisasinya. Begitu pula dengan peran tim penjamin mutu dalam pembelajaran, implementasi penjaminan mutu, penerapan manajemen mutu, implementasi pedoman standar penjaminan mutu serta keanggotaan merupakan bentuk-bentuk peningkatan kualitas yang terjadi. Penjaminan mutu juga meningkatkan kualitas melalui penyusunan pedoman penjaminan mutu yang lebih komprehensif, selain didukung oleh sarana prasarana yang memadai.

Dari sisi perencanaan kualitas catatan perbaikan, antara lain berupa dukungan kelembagaan, perencanaan strategis, tenaga kediklatan (pengelola, penyelenggara dan tenaga pengajar), sarana dan prasarana, pengembangan e-learning, pelayanan kediklatan, dan lain-lain. Data dari 53 lemdik yang dianalisis menunjukkan bahwa perencanaan kualitas tenaga kediklatan menjadi catatan penting untuk mendapatkan perhatian semua lemdik. Untuk tenaga pengajar (pengampu materi) semua lemdik (100\%) mendapatkan catatan untuk 
dilakukan perencanaan kualitas (misalnya dengan mengikutkan dalam ToT substansi dan yang paling utama terkait dengan masih minimnya pengembangan profesi tenaga pengajar yang dimiliki); sedangkan catatan dari sisi pengelola dan penyelenggara sebanyak $86,79 \%$ meliputi pemenuhan persyaratan seperti MoT dan TOC, mutasi yang terlalu cepat dan juga pengalaman yang masih harus menjadi perhatian dalam perencanaan kualitas penyelenggaraan diklat. Dari sisi penjaminan kualitas pada tahap penyelenggaraan catatan perbaikan berfokus pada perlunya lemdik $(54,72 \%)$ untuk melakukan optimalisasi instrumen monev, akurasi, partisipasi pengisian monev, obyektifitas serta penggunaan teknologi untuk pelaksanaan monev. Sedangkan dari sisi kontrol kualitas (untuk memastikan hasil sesuai dengan harapan stakeholder) tindak lanjut yang masih harus dilakukan lemdik meliputi pelayanan kediklatan, budaya mutu, integritas, diseminasi hasil pelatihan dan evaluasi kemanfaatan hasil pembelajaran sebagaimana dilihat pada Tabel 4. Dari sisi peningkatan kualitas, selain sisi pengelolaan SDM secara lebih inovatif dan pengembangan sistem kediklatan sesuai perkembangan, tindak lanjut yang perlu dilakukan lemdik adalah perbaikan dalam pengelolaan tim penjamin mutu $(75,47 \%)$, baik dari sisi penetapan tim penjamin mutu, mekanisme kerja, maupun keberadaan sarpras untuk menunjang tim penjamin mutu. Hoogveld (2018:2) ketika menggambarkan tuntutan perubahan pada sektor swasta menyebutkan bahwa tuntutan perubahan dalam organisasi semakin cepat dan juga mendalam untuk menyesuaikan dengan kebutuhan customers dalam lingkungan yang kompetitif. Tuntutan ini juga berlaku pada lemdik, untuk memiliki competitive advantages dan juga efektifitas pembelajaran, perubahan dalam bentuk continuous improvement menjadi keharusan. Continuous improvement tidak hanya berfokus pada sisi teknologi dengan software development, namun juga mencakup perbaikan pengembangan produk/jasa sesuai tuntutan publik/stakeholders/customer, strategi, model kerja, kepemimpinan, budaya, pengelolaan sumber daya manusia, perbaikan sistem, pengelolaan informasi, penelitian, dan juga penilaian kinerja (Hoogveld, 2018:4-5).

Tabel 5.

Persentase Lemdik Diberikan Catatan Perbaikan Penjaminan Kualitas Penyelenggaraan Diklat

\begin{tabular}{llr}
\hline Perencanaan Kualitas & Tenaga Pengajar & 100,00 \\
& Tenaga Kediklatan & 86,79 \\
& Pengembangan E-Learning & 75,47 \\
& Sarana dan Prasarana & 60,38 \\
& Perencanaan Strategis & 18,87 \\
Penjaminan Kualitas & Monev & 54,72 \\
Kontrol Kualitas & Pelayanan Kediklatan, Budaya Mutu, Integritas & 9,43 \\
& Diseminasi dan Kemanfaatan Hasil pembelajaran & 56,60 \\
Peningkatan Kualitas & Penjaminan Mutu & 75,47 \\
\hline
\end{tabular}

Sumber: Diolah dari Dokumentasi Berita Acara Akreditasi Tahun 2019.

Berbagai data di atas menunjukkan bahwa dari sisi hasil akreditasi, proses akreditasi selain memberikan status atau label kelayakan dalam penyelenggarakan diklat, juga memberikan rekomendasi yang harus ditindaklanjuti oleh lemdik sebagai bagian dari penjaminan kualitas. Hal ini sejalan dengan konsep Total Quality Management yang menempatkan kualitas sebagai sasaran strategis dan arah dalam praktik penyelenggaraan pengembangan kompetensi (Moracanin, 2012:201). Secara garis besar proses akreditasi mampu 
menggambarkan mengenai pelaksanaan penjaminan mutu dan juga rencana tindak lanjut yang harus dilakukan lemdik untuk memperbaiki kualitas penyelenggaraan diklat. Dari sisi perencanaan kualitas adalah tahapan yang paling membutuhkan perhatian dari lemdik karena mendapatkan catatan yang paling signifikan, dengan fokus krusial pada perencanaan tenaga pengajar. Total Quality Management (TQM) melibatkan pemahaman dan implementasi prinsip-prinsip dan konsep manajemen mutu dalam seluruh aspek kegiatan bisnis. TQM menuntut prinsip-prinsip manajemen mutu harus diterapkan dalam setiap level, setiap tahapan, setiap unit dalam sebuah organisasi (Dahlgaard, Jens J., 2005:8). Strategi transformasi tanpa perencanaan untuk implementasinya dan juga pelaksanaannya tidak akan mencapai hasil yang diinginkan (Power dan Heavin, 2018:2-3). Perencanaan kualitas dalam penyelenggaraan diklat yang tidak maksimal akan menghambat pencapaian tujuan penyelenggaraan diklat.

Jika dilihat dari sisi instrumen yang tercantum dalam pedoman pelaksanaan akreditasi, data-data yang digunakan masih cenderung menggunakan data-data statis (persyaratan dan laporan) belum menggunakan data-data dinamis yang mampu memotret indikator-indikator yang bersifat soft dalam Total Quality Management. Selain itu, transformasi teknologi juga perlu dilakukan dalam pelaksanaan akreditasi, sehingga dapat memberikan informasi yang akurat untuk pengambilan keputusan. Hal ini dilakukan agar berbagai aktivitas dalam lemdik baik proses pengambilan keputusan dan juga kemungkinan perbaikan atau perubahan dalam prosesnya seperti yang disampaikan oleh Power dan Heavin (2018:2-3) dapat diakomodir dalam transformasi teknologi lemdik.

\section{E. PENUTUP}

Manajemen kualitas yang komprehensif terutama untuk sektor pemerintah yang sifatnya birokratis menuntut adanya pengelolaan yang menyeluruh baik dari sisi perencanaan, monitoring dan control, evaluasi yang berkelanjutan serta penjaminan mutu/kualitas yang tepat. Pengaturan tertulis seperti kebijakan, prosedur baku, persyaratan/kualifikasi, kelembagaan, standar kualitas yang ditunjang dengan sistem informasi yang handal untuk memastikan kualitas pelaksanaanya. Selain aspek-aspek yang sifatnya statis tadi, aspek dinamis seperti kepemimpinan (atau kelompok manajemen) yang bertanggung jawab untuk menjamin kualitas dan juga personnel (unsur pegawai/SDM) yang melaksanakan/memenuhi pekerjaan dengan jaminan kualitas yang tinggi.

Penjaminan kualitas melalui akreditasi yang dilaksanakan saat ini prosesnya sudah efektif, sudah memenuhi aspek-aspek yang bersifat statis seperti kelembagaan, prosedur, persyaratan, pelaporan proses dan evaluasi. Namun, demikian ada beberapa perbaikan yang perlu ditambahkan, proses akreditasi secara khusus ataupun proses penjaminan kualitas secara umum harus dilihat dari siklus manajemen. Siklus manajemen harus dijadikan acuan, prinsip-prinsip manajemen mutu harus diterapkan dalam setiap level, setiap tahapan, setiap unit dalam sebuah organisasi. Selain itu, perlu penambahan data dan informasi yang mencerminkan aspek kepemimpinan, integritas dan juga informasi yang memperlihatkan komitmen pegawai dalam bekerja yang mencerminkan upaya yang dilakukan untuk memproduksi dan menjamin pemberian pelayanan kediklatan yang berkualitas. Kondisikondisi ini sangat diperlukan untuk menjamin bahwa semua aktifitas yang dilaksanakan memiliki orientasi pada pemberian pelayan yang berkualitas, yang berujung pada pencapaian tujuan pembelajaran sesuai yang diharapkan.

Aspek lain yang dapat ditingkatkan terkait dengan pemenuhan (pengisian) data dan informasi dalam pelaksanaan akreditasi, yang dilakukan tidak secara rutin. Kondisi ini menyebabkan data dan informasi yang diberikan cenderung disiapkan hanya untuk 
memenuhi keperluan akreditasi. Kondisi ini menyebabkan data dan informasi yang disajikan belum optimal untuk digunakan untuk memotret kualitas penyelenggaraan pelatihan bagi ASN. Perbaikan sistem pengelolaan data dan informasi penjaminan kualitas perlu dibangun untuk menjamin bahwa data-data yang diunggah benar-benar mencerminkan aktivitas dan penjaminan kualitas pada setiap tahapnya (up-to-date). Penjaminan mutu menjadi habit baru bagi lembaga pelatihan perlu selalu ditumbuhkan, salah satunya melalui pengembangan sistem untuk menumbuhkan budaya ini.

\section{DAFTAR PUSTAKA}

Adeoti, J. O. (2012). Redesigning the Service Process for Total Quality in Government $\begin{array}{lllll}\text { Hospitals: } & \text { Evidence from Kwara State. Intech, i(tourism), } 13 .\end{array}$ https://www.intechopen.com/books/total-quality-management-and-sixsigma/redesigning-the-service-process-for-total-quality-in-government-hospitalsevidence-from-kwara-state diakses tanggal 5 April 2020.

Al-Qahtani, N. D., Alshehri, S. S., \& Aziz, A. A. (2015). The Impact of Total Quality Management on Organizational Performance. European Journal of Business and $\begin{array}{llll}\text { Management, } & 7 & \text { Nomor } & 36 .\end{array}$ http://search.proquest.com/docview/1765981036?accountid=10297\%255Cnhttp://sfx. cranfield.ac.uk/cranfield?url_ver=Z39.88-

2004\&rft_val_fmt=info:ofi/fmt:kev:mtx:journal\&genre=article\&sid=ProQ:ProQ:abigl obal\&atitle=The+Impact+of+Total+Quality+Management+on+Firm\%25 diakses tanggal 5 April 2020.

Bendermacher, et.al. (2017). Unravelling Quality Culture In Higher Education: A Realist Review. Higher Education, 73(1), 39-60. https://doi.org/10.1007/s10734-015-9979-2

Creswell, J. W. (2014). Research Design: Qualitative, Quantitative and Mixed Methods Approaches: Fourth edition. Thousand Oaks, CA: Sage Publications.

Dahlgaard, Jens J., K. K. G. K. K. (2005). Fundamentals of Total Quality Management. Routledge.

http://libgen.is/book/index.php?md5=62629DB59E4766D153AE056B72DD58AD

DeFeo, Joseph A., J. M. J. (2014). Juran's Quality Essentials: For Leaders. MsGraw-Hill Education.

Denhardt, Janet J., R. B. D. (2007). The New Public Service: Serving, Not Steering (Expended E). United States: M. E. Sharpe, Inc. New York.

Dubey, Rameshwar, Singh, T., \& Ali, S. S. (2015). The Mediating Effect Of Human Resource On Successful Total Quality Management Implementation An Empirical Study On Smes In Manufacturing Sectors. Benchmarking: An International Journal, 22 Nomor 7.

Goestch, David L dan Davis, S. (2014). Qualitative Management for Organizational Excellent: Introduction to Total Quality (Seventh Ed). Pearson Education Limited.

Gomes, C. F., Small, M. H., \& Yasin, M. M. (2019). Towards Excellence In Managing The Public-Sector Project Cycle: A TQM Context. International Journal of Public Sector Management, 32(2), 207-228. https://doi.org/10.1108/IJPSM-11-2017-0315

Hacker, S. K., \& Washingnton, M. (2018). Lead Self First Before Leading Others. New York: Business Expert Press.

Hoogveld, M. (2018). Agile management:The Fast and Flexible Approach to Continuous Improvement and Innovation in Organizations. In IFLA Journal (Vol. 40, Issue 1). New York: Business Expert Press. https://doi.org/10.1177/0340035214526539

Johnson, M. W. (2018). Managing Using the Diamond Principle Innovating to Effect 
Improvement Managing Using the Diamond Principle (J. M. Field (ed.)). New York: Business Expert Press.

Johnstone, R. (2018). Civil Servants 'Need Devolution Training Before Starting Jobs .' https://search.proquest.com/docview/2080109017?accountid=63730 diakses tanggal 4 April 2020

Kim, G. S. (2020). The Effect Of Quality Management And Big Data Management On Customer Satisfaction In Korea's Public Sector. Sustainability (Switzerland), 12(13). https://doi.org/10.3390/su12135474

Kolibáčová, G. (2014). The Relationship Between Competency And Performance. 62(6), 1316. https://doi.org/http:dx.doi.org/10.11118/actaun201462061315

Mattingly, L. C. (2018). Managing Organizational Change The Measurable Benefits of Applied iOCM. In Enterprise Resource Planning: Concepts, Methodologies, Tools, and Applications (Vols. 3-3). New York: Business Expert Press. https://doi.org/10.4018/978-1-4666-4153-2.ch070

Mirza, M. A. (2018). Project Management And Leadership Skills Understanding Human Factors And Workplace Environment: Vol. II. New York: Business Expert Press.

Moracanin, V. (2012). Total_Quality_Management_and_Six_Sigma.pdf (T. Aized (ed.)). Croatia: InTech.

Pambreni, Y., Khatibi, A., Ferdous Azam, S. M., \& Tham, J. (2019). The Influence Of Total Quality Management Toward Organization Performance. Management Science Letters, 9(9), 1397-1406. https://doi.org/10.5267/j.msl.2019.5.011

Peraturan Kepala Lembaga Administrasi Negara Nomor 25 Tahun 2015 tentang Akreditasi Lembaga Diklat Pemerintah. (2015). Lembaga Administrasi Negara.

Peraturan Pemerintah (PP) Nomor 101 Tahun 2000 tentang Pendidikan dan Pelatihan Jabatan Pegawai Negeri Sipil. (2000).

Pertiwi, B. A. (2019). Perencanaan Kinerja Komite Penjamin Mutu Lembaga Diklat Pemerintah Daerah (Studi Pada Tim Komite Penjamin Mutu Badan Pengembangan Sumber Daya Manusia Provinsi Jawa Barat). Jurnal Ilmiah Administrasi Publik (JIAP), 5(1), 58. https://jiap.ub.ac.id/index.php/jiap diakses tanggal 5 April 2020

Pimentel, L., \& Major, M. (2016). Key Success Factors For Quality Management Implementation: Evidence From The Public Sector. Total Quality Management and Business Excellence, 27(9-10) 997-1012. https://doi.org/10.1080/14783363.2015.1055239

Power, D., \& Heavin, C. (2018). Data-Based Decision Making and Digital Transformation (D. J. Power (Ed.)). New York: Business Expert Press.

Psychogios, A. G., \& Priporas, C.-V. (2007). Understanding Total Quality Management In Context: Qualitative Research On Managers' Awareness Of TQM Aspects In The Greek Service Industry. The Qualitative Report, 12(1), 44. http://www.nova.edu/ssss/QR/QR12-1/index.html diakses tanggal 5 April 2020

Pusbangkom TSK. (2019). Laporan Penyelenggaraan Management of Training Angkatan I Tahun 2019. Jakarta

P3KBangkom ASN. (2020). Bahan Monitoring Pelatihan ASN. Jakarta

Rahman, A., \& Bakri, R. (2019). Penataan Pengelolaan Aparatur Sipil Negara (ASN) melalui Dynamic Governance. Jurnal Konstituen, 1(1), 4. https://doi.org/10.33701/jk.v1i1.309 Rhodes, M. L., et.al. (2012). Current State Of Public Sector Performance Management In Seven Selected Countries. International Journal of Productivity and Performance Management, 61(3), 235. https://doi.org/10.1108/17410401211205632

Robinson, M. (2015). From Old Public Administration to the New Public Service 
Implications for Public Sector Reform in Developing Countries. UNDP Global Centre

$$
\text { for }
$$
Public Service Excellence, $1-20$.

http://www.undp.org/content/dam/undp/library/capacitydevelopment/English/Singapore Centre/PS-Reform_Paper.pdf

Sallis, E. (2002). Total Quality Management in Education, Management Mutu Pendidikan. Yogyakarta: RCiSoD.

Smith, B. (2018). Government To 'Think Creatively ' On Cyber Security Skills - But Won ' T Commit To Extra Civil Service $\quad$ Training. 1. https://search.proquest.com/docview/2132364003?accountid=63730 diakses tanggal 5 April 2020

Susanto, A. B. (2010). Strategi Peningkatan Manajemen Mutu Pendidikan dan Pelatihan dengan Menerapkan Model Pendekatan Sistem Manajemen Mutu ISO 9001: 2008: Studi Kasus pada Pusat Pendidikan dan Pelatihan Pegawai Kementerian Pendidikan Nasional. Universitas Pendidikan Indonesia.

Thoha, M. (2008). Ilmu Administrasi Publik Kontemporer. Jakarta: Kencana.

William, T., J. S. G. (1984). Current Status of Quality Assurance in Mental Health. The American Behavioral Scientist (Pre-1986)., May/Jun 19(Political Science Database pg. 608.), 608 .

Witesman, E. M., \& Wise, C. R. (2009). The Centralization/Decentralization Paradox In Civil Service Reform: How Government Structure Affects Democratic Training Of \begin{tabular}{llllll}
\hline Civil Servants. Public Administration & Review, $69(1)$, & 116.
\end{tabular} https://doi.org/10.1111/j.1540-6210.2008.01945 
